\title{
Pengembangan Media Pembelajaran Virtual dan Interaktif Untuk Mensimulasikan Instalasi Jaringan Listrik di SMK 2 Surakarta
}

\author{
Joko Susilo7, Asrowi ${ }^{8}$, Sri Anitah 9 \\ abang_boim@yahoo.com
}

Abstract: The learning of electrical installation at Vocational High School often comes to problems as the availability of real apparatus or equipment which are not used again on the next period. It is also getting worse as the learning style is not effective by that way in a group. When it is done in a group, certain student will rely on his/her work to other friends. Consequently, they will get no beneficial from the instructional process done. Therefore, it is developed an interactive multimedia of simple electrical series in order to be directly tried by each student easily. At last, they will be motivated and get the benefit from the lesson.

Keywords: Instructional Media, Virtual Interactive Media, Simple Electrical Installation

\footnotetext{
${ }^{7}$ Mahasiswa Magister Teknologi Pendidikan Universitas Sebelas Maret Surakarta

8 Dosen Universitas Sebelas Maret Surakarta

${ }^{9}$ Dosen Universitas Sebelas Maret Surakarta
} 


\section{PENDAHULUAN}

engajaran yang didukung dengan teknologi menawarkan banyak kesempatan untuk memasukkan berbagai kemungkinan yang luar biasa ke dalam kelas. Tantangan utama dalam pendidikan berbasis teknologi informasi adalah bagaimana bisa mengembangkan pengalaman belajar yang berkontribusi terhadap pengembangan keterampilan lingkungan sambil memperluas fondasi teknik pedagogis yang diketahui. Dalam proyek ini, kami tertarik untuk mengeksplorasi penggunaan teknologi pembelajaran digital untuk meningkatkan konten dalam pembelajaran yang biasanya menggunakan alat-alat yang nyata dan menggantikannya dengan teknologi.

Penggunaan teknologi ini sendiri dipilih karena dengan menggunakan teknologi informasi dirasa akan memiliki efek yang sama apabila dibandingkan dengan menggunakan alat sebenarnya. Dengan menggunakan teknologi informasi maka bisa disimulasikan sebuah kejadian yang sesuai dengan kejadian yang nyata namun menggunakan usaha yang lebih kecil. Usaha yang dimaksud disini adalah dari sisi biaya, waktu maupun tenaga yang dikeluarkan.

Intinya kami ingin melihat apakah kami dapat melibatkan siswa dalam pembelajaran yang lebih aktif dengan memaparkannya ke teknologi audio dan video digital dan meminta mereka melakukan hal yang biasa dipraktekkan secara langsung namun dilakukan dengan simulasi. Dengan demikian, kami tertarik pada beberapa isu terkait, termasuk apakah mereka akan memilih untuk mengadopsi teknologi ini saat mereka suka rela, apakah mereka merasa berkontribusi pada pengalaman belajar positif, dan bagaimana pengaruhnya terhadap kegiatan tertentu seperti hasil dari pembelajaran itu sendiri. Harapan dari penelitian ini juga mendukung kemampuan berpikir tingkat tinggi, dan tidak hanya membahas bagaimana teknologi informasi dapat mendukung proses belajar mengajar, tetapi juga apakah gaya belajar mempengaruhi harapan dan pengalaman belajar saat terpapar media digital.

Studi ini mengacu pada beberapa bidang teori, terutama teori pembelajaran konstruktivisme dewasa yang mendukung pembelajaran aktif, dan teori gaya belajar, studi tentang preferensi belajar berdasarkan gaya belajar yang dirasakan siswa. Selain itu seiring dengan perkembangan dunia pendidikan, teknologi, dan sains membuat pendidikan tidak lagi bisa dikelola dengan hanya menggunakan pola tradisional. Sejalan dengan perubahan masyarakat untuk pengembangan teknologi dan sains, maka duni pendidikan diwajibkan memanfaatkan media teknologi untuk meningkatkan kualitas penyampaian guru dan juga daya tangkap siswa.

Selain sebagai sumber pembelajaran, guru diharuskan menggunakan alat teknologi sesuai dengan perkembangan dan tuntutan zaman ini (Alwi \& Rahmawati, 2014). Upaya yang harus dipenuhi adalah dengan memanfaatkan teknologi pembelajaran saat proses pembelajaran melalui pendekatan teknologi. Teknologi pembelajaran itu sendiri adalah media yang lahir dari perubahan komunikasi yang dapat digunakan untuk tujuan belajar disamping guru sebagai fasilitator, dan media pembelajaran seperti buku dan papan tulis (Danim, 2010). Media pembelajaran bukan hanya hal fisik, tapi segala hal yang sudah mengandung materi pembelajaran seperti buku teks, modul, benda nyata, surat kabar, video interaktif, sistem multimedia dan lain-lain, yang memungkinkan seseorang menggunakannya untuk belajar secara berurutan.

Untuk mendapatkan pengetahuan, keterampilan atau perubahan sikap. Media memiliki komponen sumber belajar dan benda fisik yang bisa digunakan untuk menyampaikan pesan agar memiliki pembelajaran yang menarik. Hal ini bertujuan untuk meningkatkan minat siswa terhadap aktivitas belajar. Rangsangan tersebut dapat dicapai jika guru mampu memilih, mengembangkan dan memanfaatkan berbagai jenis media dengan bantuan pembelajaran multimedia selama kegiatan belajar berlangsung. Sejalan dengan fungsinya yaitu membuat presentasi multimedia sendiri yang dinamis dan interaktif dengan menggabungkan teks, grafik, animasi, audio dan video. Media pembelajaran multimedia 
merupakan alat grafis, fotografi atau elektronik yang dapat digunakan untuk menangkap, mengolah, dan merekonstruksi informasi visual atau verbal (Sutirman, 2013).

Media sebagai sarana menyampaikan pesan seorang komunikator kepada komunikan memiliki peranan yang sangat penting dalam menyampaikan materi pendidikan. sebagai sarana fisik untuk menyampaikan isi materi pembelajaran apapun bentuknya seperti buku, tape recorder, kaset, kamera, video, film, slide, foto, gambar, grafik, televisi. Saat ini dengan kemajuan teknologi komputer maka muncul penggunaan media instruksional berisi komponen suara dan tampilan dimana media pembelajaran model baru ini memberikan banyak kesempatan bagi siswa untuk melakukan percobaan dan eksplorasi pada mata pelajaran yang bersangkutan dengan lebih baik. Ini bertujuan untuk memberikan pengalaman belajar daripada sekedar mendengarkan penjelasan dari guru. Media instruksional memainkan peran penting dalam mendapatkan siswa memahami materi namun dengan kemasan dan gaya yang menarik, menyenangkan, dan tidak membosankan. Selain itu, pembelajaran mereka menggunakan media berbasis komputer yang memungkinkan siswa belajar mandiri tanpa bergantung pada guru di sekolah. Disebutkan bahwa media juga bisa dijadikan guru pengganti di kelas sehingga pembelajaran tidak hanya bergantung pada guru saja (Fajriah, 2016).

Media dikembangkan berdasarkan materi pembelajaran yang harus dikuasai oleh pelajar dan dirancang sedemikian rupa sehingga materi yang ada didalamnya dapat memberikan pembelajaran yang lebih bervariasi.Diharapkan nantinya siswa yangsulit untuk mengerti dan siswa tampak pasif dan disebabkan guru yang masih menggunakan metode konvensional dalam menggunakan power point, hand out, bahan dan ringkasan sumber belajar di internet dan model pembelajaran konvensional lainnya akan menjadi lebih aktif dengan metode pembelajaran menggunakan media interaktif ini. Pembelajaran konvensional seperti ceramah dan kelompok diskusi sering akan membuat pembelajaran menjadi monoton dan kurang bervariasi.

Seels dan Glasgow memberikan klasifikasi media pembelajaran berdasarkan perkembangan teknologi media pendidikan dimana klasifikasi tersebut terdiri atasmedia tradisional misalnya gambar, slide dan foto, dan media teknologi mutakhir yang dikembangkan sesuai dengan teknologi informasi yang terbaru (Arsyad, 2011). Ada 4 manfaat yang bisa diambil dari sebuah media interaktif dalam melakukan pengajaran kepada siswa atau anak didik yaitu: untuk memperjelas penyajian pesan agar tidak terlalu bersifat verbalistis, mengatasi keterbatasan ruang, waktu, dan daya indera, dapat mengatasi sifat pasif anak didik, dan yang penting hal ini akan mempermudah guru dalam menyampaikan isi materi pelajaran (Sadiman, 2011).

Kriteria pemilihan media bersumber dari konsep bahwa media merupakan bagian dari sistem instruksional secara keseluruhan. Beberapa kriteria dalam memilih media yaitu: sesuai dengan tujuan yang ingin dicapai, mendukung isi pelajaran, praktis, luwes, guru terampil dalam menggunakannya, pengelompokkan, sasaran dan media teknis.

Dalam sebuah media pembelajaran apabila dikatakan sebagai media pembelajaran yang interaktif makna interaktif disini adalah sebagai suatu proses pemberdayaan siswa untuk mengendalikan lingkungan belajar. Sedangkan media pembelajaran interaktif adalah suatu sistem penyampaian pengajaran yang menyajikan materi video rekaman dengan pengendalian komputer kepada siswa yang tidak hanya mendengar dan melihat video dan suara, tetapi juga memberikan respon yang aktif, dan respon itu yang menentukan kecepatan dan konsekuensi penyajian (Arsyad, 2011).

Sebuah program komputer merupakan salah satu media yang dapat digunakan dalam pembelajaran dan dapat menggantikan media pembelajaran yang sebenarnya apabila dibuat sesuai dengan apa yang ada di lapangan. Selain itu dengan menggunakan program komputer yang merupakan media pembelajaran bagi siswa yang sudah disesuaikan dengan materi yang akan disampaikan atau yang harus diserap maka siswa mampu belajar secara mandiri. 
Yang menjadi keunggulan lagi bagi sebuah program pembelajaran komputer yang interaktif adalah bahwa program ini akan dapat digunakan pada berbagai jenjang pendidikan dan berbagai bidang studi. Sifat media ini selain interaktif juga bersifat multimedia terdapat unsur-unsur media secara lengkap yang meliputi animasi, video, grafis, dan sound. Selain itu dinyatakan bahwa keunggulan dari sebuah program komputer yang interaktif antara lain adalah sebagai berikut: Mampu memberikan rangsangan kepada otak karena otak tidak hanya bersifat pasif atau menunggu keterangan dari gutu saja namun juga berfikir selama proses belajar, keuntungan kedua adalahmemungkinkan adanya hubungan timbal balik antara guru dan siswa, sementara keuntungan ketiga adalahmembangkitkan motivasi belajar karena adanya variasi dalam pembelajaran, keunggulan selanjutnya adalah bahwa program interaktif ini akan memberikan pengalaman yang menyeluruh dari sesuatu yang konkret maupun abstrak karena dengan program yang interaktif ini dapat disesuaikan dengan kebutuhan yang ada (Miarso,2004)

Bentuk media pembelajaran interaktif ini bisa dibentuk dalam game dan bukan hanya modul pembelajaran yang interaktif. Game disajikan sebagai alat yang dapat dinikmati dan mengasyikkan bagi setiap orang, tantangan dalam permainan akan selalu memberikan efek ketagihan untuk selalu mencoba, mencoba dan terus mencoba hingga berhasil. Sebagai media pembelajaran, permainan mempunyai kelebihan yaitu permainan adalah sesuatu yang menyenangkan untuk dilakukan, sesuatu yang menghibur dan menarik yang memungkinkan adanya partisipasi aktif dari siswa untuk belajar, memberikan umpan balik langsung (Sadiman,2011).

Hal yang ingin dipecahkan selain media yang kurang interaktif juga keterbatasan media pembelajaraan saat melakukan praktek dimana dengan sumberdaya yang sangat terbatas maka jumlah media pembelajaran yang dibuat juga terbatas akhirnya guru biasanya memilih menggabungkan siswa namun kelompok gabungan ini terasa jumlahnya masih sangat besar. Dengan metode ini masih sering ditemui kecenderungan pasif siswa sehingga mereka lebih menunggu penjelasan guru daripada mencari dan menemukan pengetahuan, keterampilan atau sikap yang mereka butuhkan. Dengan demikian, dari masalah yang diangkat, ada kebutuhan untuk mengembangkan media pembelajaran yang mudah difahami oleh siswa namun di sisi lain juga membuat siswa aktif dalam belajar dan memiliki pengalaman dalam memecahkan masalah yang ada di lapangan.

Sebuah media pembelajaran interaktif yang sudah dibuat untuk memenuhi kebutuhan tertentu atau dirancang untuk membantu dalam melakukan sebuah pembelajaran tentunya akan membutuhkan pembuktian dalam keefektifannya. Ada beberapa kriteria yang bisa dijadikan sebagai acuan dalam melakukan review kelayakan perangkat lunak media pembelajaran yang berdasarkan pada kualitas dari media pembelajaran itu sendiri. Komponen utama untuk mengetahui kualitassuatu media pembelajaran meliputi hal-hal sebagai berikut :

Kualitas isi dan tujuan merupakan penilaian media pembelajaran yang dilihat dari segi materi yang terdapat pada media. Aspek untuk mengetahui kualitas isi dan tujuan dari media pembelajaran yang digunakan yaitu: ketepatan, kepentingan, kelengkapan, keseimbangan, minat, keadilan dan kesesuaian dengan situasi siswa.

Kualitas instruksional merupakan penilaian media pembelajaran akan kemudahan dalam penggunanan media serta dapat membantu siswa maupun guru dalam proses pembelajaran. Aspek yang terdapat pada kualitas instruksional yaitu: memberikan kesempatan belajar, memberikan bantuan untuk belajar, kualitas memotivasi, fleksibilitas instruksional, hubungan dengan program pembelajaran lainnya, kualitas sosial interaksi, memberi dampak bagi siswa, membawa dampak bagi guru dan pembelajarannya

Kualitas teknis merupakan penilaian terhadap tampilan atau tayangan pada media pembelajaran. Aspek untuk menilai kualitas teknis yaitu: keterbacaan, mudah digunakan, kualitas tampilan atau tayangan, kualitas penanganan program, dan kualitas pendokumentasian. Model pengembangan perangkat pembelajaran yang disarankan oleh Thiagarajan, Semmel, dan Semmel (dalam Ibrahim, 2001), adalah model 4-D (Four D Models). Model initerdiri dari 4 tahap pengembangan yaitu: 
Tahap I: Define (Pendefinisian)

Dalam tahap ini terdapat beberapa analisa yang harus dilakukan untuk memastikan bahwa media pembelajaran yang akan dibuat nantinya akan memenuhi tujuan pembuatan media pembelajaran itu sendiri. Analisa pertama yang harus dilakukan adalah analisis ujung depan yang bertujuan untuk memunculkan dan menetapkan masalah dasar yang dihadapi dalam pembelajaran, sehingga diperlukan suatu pengembangan media; yang kedua adalahanalisis siswa yaitu telaah tentang karakteristik siswa yang berkaitan dengan topik pembelajaran, format media;selanjutnya analisa ketiga yang harus dilakukan yaituanalisis konsep untuk memenuhi prinsip kecukupan dalam membangun konsep atas materi yang digunakan sebagai sarana pencapaian kompetensi dasar dan standar kompetensi; selanjutnya adalah analisis tugas untuk mengidentifikasi dan menganalisis keterampilan utama yang akan dikaji oleh peneliti; sedangkan langkah yang diambil setelah semua analisa tersebut selesai adalah perumusan tujuan pembelajaran yang berguna untuk merangkum hasil dari analisis konsep dan analisis tugas.

\section{Tahap II: Design (Perancangan)}

Setelah semua analisa selesai maka dilakukanlah tahapan selanjutnya yaitu tahapan perancangan. Ada empat langkah yang harus dilakukan pada tahap ini, yaitu: penyusunan standar tes dimana ini akan digunakan untuk memastikan kembali hasil yang didapat dari pembelajaran, langkah yang kedua adalah pemilihan media yang sesuai dengan karakteristik materi dan tujuan pembelajaran, langkah ini penting karena media interaktif yang akan digunakan nanti harus sesuai dengan karakteristik siswa yang akan menerima pembelajaran ini. Langkah selanjutnya adalah pemilihan format dimana ini akan menentukan bagaimana media interaktif ini akan dibuat dan apa yang akan digunakan untuk mengembangkannya dan langkah terakhir pada tahapan ini adalah membuat rancangan awal sesuai format media.

Tahap III: Develop (Pengembangan)

Tahap untuk menghasilkan produk pengembangan yang dilakukan melalui dua langkah penting setelah draft atau bentuk awal dari media sudah terbentuk. Langkah yang pertama adalah membawa rancangan tersebut kepada ahli yang dianggap mampu untuk memberikan penilaian sejaun mana media pembelajaran ini akan cocok bila diterapkan untuk melakukan sebuah pembelajaran. Setelah adanya penilaian dari ahli maka yang harus dilakukan adalah melakukan revisi sesuai dengan saran ahli tersebut dimana ini akan menyempurnakan konsep awal dari media interaktif ini. Masukan dari ahli ini diharapkan akan membuat media interaktif ini lebih sesuai dengan tujuan pengembangannya. Setelah berbagai masukan dari ahli diterima dan beberapa revisi dilakukan berdasarkan saran dari para ahli tersebut maka yang dilakukan selanjutnya adalah melakukan uji coba terhadap hasil pengembangan yang sudah dilakukan dengan mengujicobakan pada objek yang nantinya akan menggunakan media tersebut yaitu siswa itu sendiri. Dengan uji coba ini akan didapat juga beberapa data apakah media kita cocok dengan karakteristik mereka dan sudah dapat meningkatkan pemahaman mereka terhadap sebuah mata pelajaran tertentu sesuai dengan level yang kita harapkan atau tidak. Intinya percobaan pada siswa ini akan memastikan sejauh mana ketertarikan mereka terhadap media interaktif yang sudah dikembangkan dan apakah media tersebut sudah membantu para siswa untuk belajar dan memahami apa yang dipelajari melalui media tersebut.

Tahap IV: Disseminate (Penyebaran)

Tahap diseminasi dilakukan untuk mempromosikan produk pengembangan agar bisa diterima pengguna. Ini merupakan tahap akhir jika produk sudah dinyatakan baik oleh ahli dan sudah dicobakan pada beberapa siswa dan berhasil sesuai dengan yang diharapkan.

\section{METODE PENELITIAN}

Dalam melakukan penelitian kali ini maka dipilih mata pelajaran yang akan digunakan sebagai objek dari penelitian ini sendiri. Adapun mata pelajaran yang dipilih adalah instalasi listrik. Alasan pemilihan mata pelajaran kali ini adalah bahwa mata pelajaran yang akan disimulasikan atau dibuatkan media 
pembelajaran virtual dan interaktifnya adalah karena mata pelajaran ini biasanya akan membutuhkan banyak sekali biaya apabila mempraktekkan secara langsung dan apabila terdapat kesalahan dalam melakukan instalasi atau pemasangannya maka media pembelajaran akan tidak bisa dipakai.

Untuk penelitian dipilih SMK 2 Surakarta yang memiliki jurusan listrik dalam salah satu program studinya. SMK 2 Surakarta sendiri adalah SMK yang dulu dikenal sebagai STM Solo. STM Solo didirikan pada tanggal 1 Juli 1952 berlokasi di Gendengan Solo, lokasi STM Negeri Solo, yang sejak tahun 1998 menjadi SMP Negeri 24 dan SMP Negeri 25 Surakarta.Jurusan yang dibuka saat itu ada tiga jurusan yaitu bangunan, mesin dan listrik

Pada tanggal 22 Juli 1952 terbit surat Keputusan Menteri Pengajaran dan Kebudayaan Republik Indonesia No. 3095/B. Maka STM Solo resmi menjadi STM Negeri Solo dengan pimpinan Bp. Ir. Frederik Camalius Lovis Olden (sebutan akrabnya Bp. Ir. Olden ). Pada tahun 1956 STM Negeri Solo memperoleh tanah seluas 25.150 meterpersegi dari pemerintah daerah yang terdapat di jalan Adisucipto No. 3 Manahan Kecamatan Banjarsari, Kotamadya Solo dengan Kepala Sekolah Bapak Soedirman.

Dari mulai berdiri tahun 1952 hingga tahun 1998 pejabat Kepala Sekolah sejumlah 12 orang dengan 4 periode peningkatan. Periode ke 1. Tahun 1952 saat berdiri Kepala Sekolah Bapak Ir.FC.I. Van Olden Tahun 1956 mendapat lokasi di jalan Adisucipto No. 3 dengan Kepala Sekolah Bapak Soedirman.Tahun 1966 menjadi Stm Negeri 1 Surakarta dengan Kepala Sekolah Bapak RM. Soekarso Atmodipuro.Tahun 1971 mendapat proyek pertama, Pembuatan Ruang / bengkel kerja Mesin, Kepala Sekolah Bapak Iskandar Isman Djojo Hasmoro, dengan menggunakan kurikulum 1964.

Periode ke 2. Tahun 1977 dengan SK. Dikmenjur tertanggal 6 januari 1977No. 5.1.012.77 ditunjuk melaksanakan kurikulum 1967 (STM 3 Tahun ) dengan pengembangan jurusan dimana jurusan yang dikembangkan antara lain menjadi mesin, bangunan, listrik, elektronika danotomotif.

Periode ke 3. Tahun 1986 dengan SK. Dikmenjur tertanggal 4 Desember 1996 No. 267/C4/Kep/1.86 menetapkan STM Negeri 1 Surakarta untuk melaksanakan Rumpun / program Studi yang terdiri dari 4 rumpun yaitu bangunan yang terdiri atas bangunan gedun dan gambar bangunan. Yang kedua adalah rumpun elektronika dimana dibawahnya muncul elektronika komunikasi. Sebuah rumpun baru adalah rumpun Teknologi Pengerjaan Logam dimana di bawahnya terdapat bidang mesin Produksi. Yang terakhir yaitu rumpun otomotif dengan program studi mekanik Otomotif.

Dibawah pimpinan Bapak Soeparno, BE Dengan kurikullum 1984 serta melaksanakan program Pengembangan Sekolah Seutuhnya (PSS). Periode ke 4. Tahun 1994 berlaku perubahan rumpun menjadi jurusan, maka STM 1 Surakarta memiliki 5 jurusan dengan 6 program studi. Adapun jurusan yang ada yaitu Jurusan Bangunan, Elektronika, Listrik, Teknologi Pengerjaan Logam dan jurusan Otomotif. Berada di bawah jurusan secara struktural ada beberapa program studi dimana untuk Jurusan bangunan memiliki 2 program studi yaitu program studi gambar bangunan dan program studi bangunan gedung. Untuk jurusan elektronika program studi yang ada di bawahnya yaitu elektronika komunikasi sedangkan untuk Jurusan Listrik program studi yang dibawahnya adalah program studi Listrik terapan. Untuk jurusan Teknologi Pengerjaan Logam membawahi program studi Mesin produksi dan Jurusan yang terakhir yaitu otomotif membawahi program studi mekanik otomotif.

Dengan melaksanakan kurikullum 1994 dan beban spesifik pendidikan Sistem Ganda menjadi SMK Negeri 2 Surakarta Tahun Pelajaran 1997/1998. Pada Tahun Pelajaran 1999/2000 pada SMK Negeri 2 Surakarta diberlakukan dengan adanya Program Keahlian dan bidang keahlian yang meliputi bidang keahlian bangunan, bidang keahlian elektronikan dan bidang keahlian mesin. Untuk Bidang keahlian bangunan memiliki tiga program keahlian yaitu program keahlian teknik perkayuan, program keahlian teknik konstruksi bangunan, dan program keahlian teknik gambar bangunan. Dari bidang keahlian elektronika ada dua program keahlian yaitu program keahlian teknik audio video dan program keahlian listrik terapan. Untuk bidang keahlian mesin dibagi juga menjadi dua yaitu program keahlian mesin perkakas dan program keahlian mekanik otomotif. 
Periode ke 5. Tahun 2003 menambah Program Studi Teknologi Informasi dengan Program Keahlian Teknologi Informasi dan Komunikasi. Pada tahun 2004 ditetapkan dengan Surat Keputusan Dinas Pendidikan Pemuda dan Olahraga Kota Surakarta No. 421.2/2372/SM/2004.Dan masih melaksanakan Program Pendidikan Sistem Ganda, dari Tahun Pelajaran 1997 / 1998 sampai 2002 / 2004 yang dipimpin oleh Mr. Drs. Suwardi. Sedang Tahun Pelajaran 2004 / 2005 yang dipimpin oleh Mr. Drs. Rakhmat Sutomo.

Dalam melakukan penelitian yang merupakan merupakan penelitian pengembangan ini model pengembangan yang diacu adalah modelpengembangan yang terdiri dari tahapan pengembangan yaitu Define, Design, and Develop, yang diadaptasi dari Thiagarajan, Semmel dan Semmel dalam Ibrahim, (2001). Model ini dipilih karena tahapan pengembangannya tersusun secara sistematis sehingga mempermudah peneliti dalam pelaksanaan untuk masing-masing langkah pengembangan serta parameter-parameter yang diinginkan dapat terkontrol dengan baik

Sesuai dengan langkah diatas makan yang dilakukan pertama kali adalah pendifinisian kebutuhan melalui beberapa analisa. Prosedur Pengembangan yang harus dilalui meliputi analisa pertama yaitu: analisis ujung depan yang bertujuan untuk memunculkan dan menetapkan masalah dasar yang dihadapi dalam pembelajaran, sehingga diperlukan suatu pengembangan media; yang kedua adalah analisis siswa yaitu telaah tentang karakteristik siswa yang berkaitan dengan topik pembelajaran, format media; selanjutnya analisa ketiga yang harus dilakukan yaitu analisis konsep untuk memenuhi prinsip kecukupan dalam membangun konsep atas materi yang digunakan sebagai sarana pencapaian kompetensi dasar dan standar kompetensi; selanjutnya adalah analisis tugas untuk mengidentifikasi dan menganalisis keterampilan utama yang akan dikaji oleh peneliti; sedangkan langkah yang diambil setelah semua analisa tersebut selesai adalah perumusan tujuan pembelajaran yang berguna untuk merangkum hasil dari analisis konsep dan analisis tugas.

Selanjutnya dibuatlah sebuah model nyata dari media pembelajaran interaktif sesuai dengan hasil analisa yang ada. Harapan dari penelitian ini dimaksudkan untuk mengembangkan media pembelajaran virtualyang interaktif berkaitan dengan mata pelajaran instalasi listrik sebagai produk penelitian. Setelah penyelesaian model dari media interaktif ini sudah diselesaikan maka langkah selanjutnya yang dilakukan adalah uji coba produk

Uji coba produk dimaksudkan untuk mengumpulkan data yang dapat digunakan sebagai dasar untuk menetapkan tingkat keefektifan dan efisiensi dari produk yang dihasilkan melalui penilaian terhadap media virtual interaktif yang baru dibuat tersebut. Dalam pelaksanaan uji coba produk secara terbatas perlu dilakukan lima tahap yaitu dimulai dengan tahap desain uji coba.

Dalam melakukan desain uji coba juga dilakukan dalam beberapa tahapan dimana dimulai dengan uji siswa perseorangan, uji kelompok kecil sebanyak 30 siswa SMK 2 Surakarta program studi listrik, dan uji lapangan yaitu observasi langsung dengan siswa uji coba yang lebih besar. Adapun materi yang dipilih untuk media pembelajaran ini adalah materi instalasi listrik sederhana.

Jenis data penelitian ini adalah data kualitatif dan data kuantitatif. Data kualitatif adalah data yang berbentuk kata, kalimat, skema dan gambar. Dalam penelitian ini data kualitatif diperoleh dari hasil telaah media oleh ahli materi, ahli media, dan siswa yaitu berupa angket telaah media yang digunakan untuk memberikan kritik dan masukan untuk kesempurnaan media tersebut. Data kuantitatif adalah data yang berbentuk angka yang kemudian dianalisis dengan teknik persentase. Dalam penelitian inidata kuantitatif diperoleh dari hasil validasi oleh para ahli yaitu ahli materi, dan ahli media. Data tersebut berupa skor penilaian kelayakan media dari ahli materi dan ahli media. (Sugiyono, 2006)

Dalam pengmpulan data dibutuhkan instrumen pengumpulan data. Instrumen adalah alat bantu atau fasilitas yang digunakan dalam mengumpulkan data secara cermat, lengkap, dan sistematis sekaligus mudah diolah dengan hasil yang lebih baik (Riduwan, 2011). Adapun instrumen pengumpulan data yang digunakan dalam penelitian ini adalah observasi melalui lembar observasi dan kuesioner 
melalui lembar angket yang terdiri dari angket terbuka dan tertutup yang disebar kepada objek penelitian baik kepada tenaga ahli maupun kepada siswa.

Observasi dilakukan pada waktu siswa melakukan uji coba terbatas terhadap media pembelajaran dari program virtual interaktif yang dikembangkan. Hasil observasi digunakan untuk mengetahui keefektivitasan pembelajaran penyusunan instalasi listrik dengan menggunakan media pembelajaran virtual interaktif. Dari observasi ini diharapkan akan didapatkan data sejauh mana media pembelajaran yang dibuat sesuai dengan kebutuhan pembelajaran yang ada dan sejauh mana siswa dapat menikmati atau tertarik dengan media ini.

Dalam melakukan observasi digunakan angket terbuka dan angket tertutup. Angket terbuka adalah angket yang disajikan dalam bentuk sederhana sehingga responden dapat memberikan isian sesuai dengan kehendak dan keadaannya. Sedangkan angket tertutup adalah angket yang sudah disediakan jawabannya sehingga responden tinggal memilih. Angket tertutup sudah disediakan alternatif jawaban sehingga jawaban dari responden sesuai dengan batasan yang disediakan (Riduwan, 2011)

Untuk penelitian ini angket terbuka diserahkan kepada ahli materi dimana ini bertujuan untuk melakukan telaah yang diperlukan sebelum program tersebut didesain dan selama proses desain diharapkan sedapat mungkin akan mendekati kenyataan atau akan menghasilkan produk yang sesuai dengan yang diharapkan. Instrumen penelitian ini diisi oleh dua orang ahli materi yaitu guru mata pelajaran instalasi listrik di SMK 2 Surakarta untuk memperoleh pendapat dan masukan tetang draft awal media virtual interaktif pada materi instalasi listrik dasar sehingga didapatkan media yang lebih baik.

Angket terbuka juga diberikan untuk mendapatkan kesesuaian materi dari draft media virtual interaktif ini maka juga diberikan angket telaah Ahli Media dimana instrumen angket ini juga diisi oleh dua orang ahli materi yaitu guru mata pelajaran instalasi listrik di SMK 2 Surakarta untuk memperoleh pendapat dan masukan tetang draft awal media virtual interaktif pada materi instalasi listrik dasar berdasarkan kriteria kesesuaian materi dengan standarkompetensi yang ada dan juga kurikulum yang diacu oleh SMK sehingga akan didapatkan sebuah media virtual interaktif yang sesuai dengan kompetensi dasar yang berlaku sehingga didapatkan media yang lebih baik dan sesuai dengan tuntutan pencapaian kompetensi yang ada.

Angket selanjutnya adalah angket telaah untuk siswa dimana instrumen penelitian ini diisi oleh 20 orang siswa di SMK 2 Surakarta untuk memperoleh pendapat dan masukan tetang draft awal media virtual interaktif pada materi instalasi litrik dasar berdasarkan kriteria kesesuaian materi dengan standar kompetensi dasar yang berlaku sehingga didpatkan media yang lebih baik.

Selain angket terbuka maka juga disebarkan angket tertutup dimana angket ini diberikan kepadaahli materi untuk melakukan validasi dari materi yang ada dalam media virtual interaktif yang dirancang. Instrumen angket tertutup ini diisi oleh ahli materi setelah mencoba media virtual interaktif yang sudah dikembangkan sesuai dengan data-data yang sudah terkumpul sebelumnya melalui angket terbuka yang sudah dianalisa. Angket ini bertujuan untuk mengetahui kelayakan media virtual interaktif pada materi instalasi listrik.

Angket validasi ahli media juga diberikan dalam bentuk angket tertutup dimana angket validasi ahli media ini diisi oleh ahli media setelah mencoba media virtual interaktif yang dikembangkan. Angket ini bertujuan untuk mengetahui kelayakan media virtual interaktif pada materi instalasi listrik sudah layak untuk digunakan dan dilakukan uji coba yang sesuangguhnya apda siswa atau belum.

Setelah semua angket terkumpul maka dilakukan analisa data yang didapat dari angket tersebut. Data yang dianalisis adalah data angket yang terdiri dari:

a. Angket telaah ahli materi dan ahli media dianalisis secara kualitatif untuk memberikan gambaran dari saran yang telah diberikan sehingga kekurangan media terkait dengan format dan kualitas media, 
dan konsep materi yang digunakan dalam media virtual interaktif mengenai pembelajaran tentang instalasi listrik.

b. Angket validasi oleh ahli materi dan ahli media dianalisis secara kuantitatif. Kriteria penilaian kelayakan media pembelajaran diadaptasi dari Walker dan Hees (dalam Arsyad, 2011) yang berdasarkan tiga aspek yaitu kualitas isi dan tujuan, kualitas instruksional dan kualitas teknis. Prosentase tersebut diperoleh dengan berdasarkan perhitungan skor menurut Riduwan (2011) dalam skala likert.

Untuk menghitung persentase kelayakan dari setiap indikator, rumus yang digunakan adalah sebagai sebagai berikut:

$$
K=\frac{F}{N \times I \times R} \times 100 \%
$$

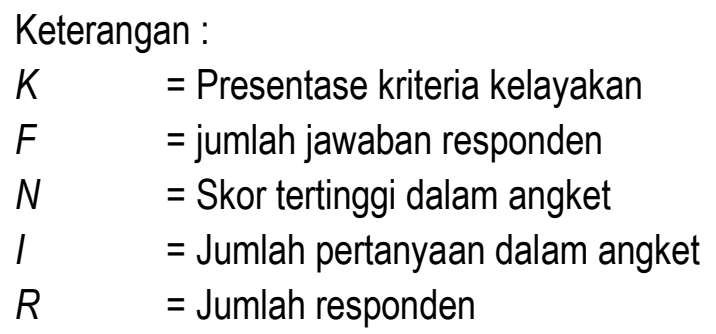

Hasil perhitungan persentase dari angket validasi diinterpretasikan ke dalam skor. Kriteria interprestasi skor yang digunakan diadaptasi dari Riduwan (2011), yaitu persentasi 0\%-20\% masuk dalam kategori sangat tidak layak, persentase 21\%-40\% masuk dalam kategori tidak layak, $41 \%-60 \%$ masuk dalam kategori kurang layak, 61\%-80\% masuk dalam kategori layak dan $81 \%-100 \%$ masuk dalam kategori sangat layak.

Angket respon siswa dianalisis secara kuantitatif. Penilaian media berdasarkan aspek format media, kualitas media dan ketertarikan siswa. Persentase tersebut diperoleh dengan berdasarkan perhitungan skala guttman menurut Riduwan (2010), yaitu untuk jawaban ya mendapatkan nilai 1 dan untuk jawaban tidak mendapatkan nilai 0 .

Data hasil angket validasi dan uji coba terbatas kemudian dianalisis dengan cara yang sama dengan angket sebelumnya dan hasil perhitungan persentase dari angket respon siswa diinterpretasikan ke dalam skor. Kriteria prosentase respon yang digunakan diadaptasi dari Riduwan (2011), yaitu persentasi 0\%-20\% masuk dalam kategori sangat tidak layak, persentase $21 \%-40 \%$ masuk dalam kategori tidak layak, 41\%-60\% masuk dalam kategori kurang layak, 61\%-80\% masuk dalam kategori layak dan 81\%$100 \%$ masuk dalam kategori sangat layak.

\section{HASIL DAN PEMBAHASAN}

Berdasarkan hasil observasi pada siswa kelas XI SMK 2 Surakarta didapatkan hasil bahwa media pembelajaran yang digunakan oleh guru bidang studi ekonomi pada materi tersebut adalah media papan tulis, powerpoint dan alat peraga yang berupa perengkapan riil yang harus dibeli dengan harga yang cukup mahal karena setelah penggunaan perlengkapan ini banyak tidak terpakai.

Media powerpoint dan papan tulis digunakan pada saat teori awal pembelajaran instalasi listrik sederhana sedangkan materi selanjutnya menggunakan media alat praktek langsung yang menjadikan siswa kurang tertarik dan kurang memperhatikan materi tersebut.Sikap siswa yang beranggapan bahwa 
materi instalasi listrik sederhana adalah materi yang kurang menarik dalam mata pelajaran listrik dan media pembelajaran yang membosankan dan tidak mencukupi menyebabkan tidak banyak siswa kelas $\mathrm{XI}$ yang menyukai mata pelajaran tersebut.

Proses Pengembangan Media Pembelajaran media virtualinteraktif pada materi instalasi listrik sederhana untuk siswa kelas XI SMK 2 Surakarta. Pengembangan media pembelajaran virtual interaktif ini menggunakan model pengembangan yang dikembangkan oleh Thiagarajan yang terdiri dari tahap pendefinisian (Define), tahap perancangan (Design), dan tahap pengembangan (Develop).

Tahap-tahap yang dilakukan pada penelitian dan pengembangan media interaktif ini akan dijelaskan lebih lanjut sebagai berikut:

\section{Tahap Pendefinisian}

Tahap pendefinisian dilakukan dengan menganalisis tujuan dalam batasan materi pelajaran yang akan dikembangkan. Ada 5 langkah pokok di dalam tahap ini, langkah-langkah itu antara lain:

Analisis Ujung Depan merupakan langkah pertama dimanatujuan analisis ujung depan adalah untuk memunculkan masalah dasar yang dibutuhkan dalam pengembangan media pembelajaran. Beberapa hal yang perlu dipertimbangkan dalam analisis ujung depan diantaranya. Kesulitan siswa kelas XI SMK 2 Surakarta dalam pemahaman materi instalasi listrik sederhana yaitu pada konsep materi instalasi listrik sederhana yang bersifat terlalu sederhana dan media pembelajaran papan tulis dan powerpoint yang digunakan oleh guru dianggap kurang menarik dan membosankan bagi siswa.

Tantangan dan tuntutan di masa depan adalah siswa diharapkan menjadi pembelajar yang mandiri dengan kompetensi yang dimiliki. Alternatif penyelesaian masalah dan untuk menghadapi tuntutan tersebut yaitu diperlukan adanya pengembangan terhadap media pembelajaran pada materi instalasi listrik sederhana yang menarik dan tidak membosankan untuk siswa, harapannya agar pengembangan media tersebut dapat menunjang proses pembelajaran pada materi tersebut salah satunya dengan menggunakan pengembangan media pembelajaran virtual yang interaktif

Langkah kedua adalah analisis siswaSiswa yang menjadi sasaran uji coba media adalah siswa kelas XI SMK 2 Surakarta. Rata-rata usia siswa kelas XI SMK 2 Surakarta adalah 16-18 tahun, dimana perkembangan kognitif siswa pada tahap operasi formal yakni dapat berfikir secara logis. Berdasarkan nilai ulangan harian didapatkan siswa yang nilainya tuntas sebanyak 20 siswa pada kelas XI. Maka didapatkan hasil bahwa siswa kelas XI mengalami kesulitan pada materi instalasi listrik sederhana tersebut.

Selain itu siswa kelas XI SMK 2 Surakarta juga telah mampu mengoperasikan komputer secara aktif. Pelajaran TIK (Teknologi Informatika Komputer) telah didapatkan siswa sejak berada di bangku kelas X sehingga padakelas XI siswa telah mampu mengoperasikan komputer.

Langkah ketiga dari tahap ini adalah analisis tugas dimana analisis tugas ini bertujuan untuk mengidentifikasi tugas-tugas yang harus dilakukan oleh siswa dalam mencapai kompetensi dasar dan indikator ketuntasan. Tugas siswa yakni membuka program pembelajaran yang terdapat dalam media virtual interaktif, Mempelajari materi pembelajaran dan mencoba mengaplikasikan teori yang sudah didapat secara praktek walaupun dengan cara simulasi.

Langkah selanjutnya adalah analisis konsep dimana analisis konsep merupakan kegiatan identifikasi terhadap konsep utama yang akan diajarkan dan menyusun secara sistematis dengan merinci konsep yang relevan yang disajikan ke dalam peta konsep materi.

Setelah semua analisa dilakukan maka kemudian dilakukan perumusan tujuan pembelajaran. Tujuan pembelajaran materi pokok instalsasi listrik dasar dapat dijabarkan sebagai berikut:

1. Kognitif 
a. Siswa dapat menjelaskan pengertian dan susunan rangkaian listrik sederhana.

b. Siswa dapat membuat susunan instalasi listrik sederhana.

c. Siswa dapat menyusun instalasi listrik sederhana dengan benar.

\section{Psikomotor}

Siswa dapat mengoperasikan media pembelajaran virtual interaktif dengan baik dan

\section{Afektif}

mengaplikasikan masalah yang ada di lapangan

Siswa dapat tertarik untuk belajar materi instalasi listrik sederhana perusahaan jasa menggunakan media pembelajaran virtual interaktif.

\section{Tahap Perancangan}

Penyusunan materi dan simulasi yang meliputi pengertian dari instalasi listrik sederhana, menjelaskan tujuan dari penyusunan rangkaian listrik seri dan pararel serta menyebutkan keuntungan dan kerugian dari masing-masing rangkaian instalasi listrik.

Hasil dari penelitian pengembangan ini adalah terciptanya sebuah produk media pembelajaran berbasis multimedia yang disajikan dalam bentuk permainan puzzle dan di integrasikan ke dalam bentuk software interaktif yang siap di pasang atau diinstal pada setiap komputer dengan berbagai jenis sitem operasi.Untuk itu pengembang menggunakan menggunakan software pemrograman $\mathrm{C}++$ digunakan sebagai sarana pembantudalam proses pembelajaran listrik khususnya materi instalasi listrik sederhanabaik itu berupa rangkaian seri maupun pararel.

Untuk tahapan pengembangan tahap pengembangan dengan tujuan untuk menghasilkan media pembelajaran yang sudah direvisi berdasarkan masukan dari para ahli. Tahap ini diawali dengan telaah dari para ahli kemudian menghasilkan revisi sesuai dengan masukan telaah para ahli. Selanjutnya, dilakukan validasi untuk mengetahui kelayakan media yang dikembangkan sebelum dilakukan uji coba terbatas.

Dari hasil analisa kelayakan media pembelajaranvirtualinteraktif pada materi instalasi listrik untuk siswa kelas XI SMK 2 Surakarta maka didapatkan hasil sebagai berikut:

Tabel 1. Analisa Kelayakan Media Pembelajatan Virtual Interaktif oleh Ahli Materi

\begin{tabular}{|c|l|r|l|}
\hline No & \multicolumn{1}{|c|}{ Aspek } & Prosentase & Kategori \\
\hline 1 & Instruksional & $81,30 \%$ & sangat layak \\
\hline 2 & Isi danTujuan & $82,10 \%$ & sangat layak \\
\hline 3 & Teknis & $84,30 \%$ & sangat layak \\
\hline & Total & $247,70 \%$ & \\
\hline & Rata-rata & $82,57 \%$ & sangat layak \\
\hline
\end{tabular}

Berdasarkan tabel diatas, didapatkan hasil validasi media oleh ahli materi yaitu aspek instruksional sebesar $81,30 \%$, aspek isi dan tujuan sebesar $82,1 \%$, danaspek teknik sebesar $84,3 \%$, maka nilai ratarata presentase media Media virtual interaktif oleh ahli materi sebesar $82,57 \%$ apabila diinterpretasikan menurut Riduwan (2011), dalam skala likert persentase sebesar $>81 \%$ termasuk dalam kriteria sangat layak.Sedangkan hasil validasi media oleh ahli media menunjukkan hasil yang juga sangat memuaskan seperti terlihat dari hasil berikut: 
Tabel 2. Analisa Kelayakan Media Pembelajatan Virtual Interaktif oleh Ahli Media

\begin{tabular}{|c|l|r|l|}
\hline No & \multicolumn{1}{|c|}{ Aspek } & Prosentase & \multicolumn{1}{|c|}{ Kategori } \\
\hline 1 & Instruksional & $82,70 \%$ & sangat layak \\
\hline 2 & Isi danTujuan & $81,10 \%$ & sangat layak \\
\hline 3 & Teknis & $86,30 \%$ & sangat layak \\
\hline & Total & $250,10 \%$ & \\
\hline & Rata-rata & $83,37 \%$ & sangat layak \\
\hline
\end{tabular}

Berdasarkan tabel diatas, didapatkan hasil validasi media oleh ahli materi yaitu aspek instruksional sebesar $82,70 \%$, aspek isi dan tujuan sebesar $81,1 \%$, danaspek teknik sebesar $86,3 \%$, maka nilai ratarata presentase media Media virtual interaktif oleh ahli materi sebesar $83,37 \%$ apabila diinterpretasikan menurut Riduwan (2011), dalam skala likert persentase sebesar $>81 \%$ termasuk dalam kriteria sangat layak.

Untuk langkah selanjutnya melihat respon siswa kelas XI SMK 2 Surakartaterhadap pengembangan media pembelajaran media virtual interaktif pada materi instalasi listrik sederhana. Setelah melakukan uji coba terbatas, siswa diminta memberikan pendapat atau respon terhadap pembelajaran instalasi listrik sederhana dengan menggunakan media pembelajaran media virtual interaktif yang telah dilakukannya. Hasil respon siswa tersebut disajikan dalam tabel respon siswa terhadap media virtual interaktif.

Berdasarkan tabel diatas, didapatkan hasil respon siswa terhadap media Media virtual interaktif oleh 20 siswa kelas XI SMK 2 Surakarta yaitu format media sebesar 82,4\%, kualitas media sebesar 81,8\%, dan ketertarikan siswa sebesar $87,3 \%$, maka nilai rata-rata presentase media Media virtual interaktif oleh siswa sebesar $83,83 \%$ apabila diinterpretasikan menurut Riduwan (2011), dalam skala likert persentase sebesar $>81 \%$ termasuk dalam kriteria sangat layak.

Tabel 3. Respon Siswa Terhadap Media Virtual Interaktif

\begin{tabular}{|c|l|r|l|}
\hline No & \multicolumn{1}{|c|}{ Aspek } & Prosentase & Kategori \\
\hline 1 & Kualitas Media & $81,80 \%$ & sangat layak \\
\hline 2 & Ketertarikan Siswa & $87,30 \%$ & sangat layak \\
\hline 3 & Format Media & $82,40 \%$ & sangat layak \\
\hline & Total & $251,50 \%$ & \\
\hline & Rata-rata & $83,83 \%$ & sangat layak \\
\hline
\end{tabular}

\section{KESIMPULAN}

Berdasarkan dari hasil pembahasan diatas, maka kesimpulan dalam penelitian ini adalah proses pengembangan media pembelajaran Media virtual interaktif pada materi instalasi listrik sederhana untuk siswa kelas XI SMK 2 Surakarta menggunakan model pengembangan menurut teori Thiagarajan dalam Ibrahim (2001), yang terdiri dari tahapan pengembangan yaitu Define, Design, and Develop terbukti layak untuk digunakan.Kelayakan dari pengembangan media pembelajaran media virtual interaktif pada materi instalasi listrik sederhana siklus akuntansi perusahaan jasa untuk siswa kelas XI SMK 2 Surakarta termasuk dalam kategori sangat layak untuk digunakan sebagai media pembelajaran dan ini disambut oleh anak didik SMK 2 Surakarta dimana respon siswa kelas XI SMK 2 Surakarta terhadap pengembangan media pembelajaran media virtual interaktif pada materi instalasi listrik sederhana termasuk dalam kategori sangat baik atau layak untuk digunakan sebagai media pembelajaran. 


\section{SARAN}

Berdasarkan dari kesimpulan diatas, maka saran dalam penelitian ini adalah media pembelajaran Media virtual interaktif pada materi instalasi listrik sederhana ini hanya sampai pada tahap pengembangan (Develop). Oleh karena itu, perlu dilakukan lebih lanjut pada tahap penyebaran (Dessiminate); penelitian pengembangan media pembelajaran Media virtual interaktif pada materi instalasi listrik sederhana ini hanya sebatas menguji kelayakan media yang di tentukan berdasarkan penilaian angket dari validasi ahlimateri dan ahli media serta pendapat siswa. Oleh karena itu, perlu dilakukan penelitian lebih lanjut tentang kelay akan media sampai pada hasil belajar yang dicapai siswa setelah menggunakan media yang dikembangkan; penelitian pengembangan media pembelajaran Media virtual interaktif ini hanya terbatas pada materi instalasi listrik sederhana. Oleh karena itu, perlu dilakukan pengembangan media lebih lanjut pada materi akuntansi yang lainnya.

\section{DAFTAR PUSTAKA}

Arsyad, A. (2011). Media Pembelajaran. Jakarta: PT Raja Grafindo Persada

Ibrahim. (2001). Pengembangan Perangkat Pembelajaran. Jakarta: Depdiknas

Alwi, M. F., \& Rakhmawati, L. (2014). Pengembangan Media Pembelajaran Computer Based Instruction (CBI) Menggunakan Adobe Flash CS4 dan DSCH2 pada Materi Menerapkan dan Menguji MacamMacam Rangkaian Flip-Flop di SMKN 7 Surabaya. Jurnal Pendidikan Teknik Elektro, 3 (3), pp. 535-541.

Miarso, Y. (2004). Menyemai Benih Teknologi. Jakarta: Kencana

Riduwan. (2011). Skala Pengukuran Variabel-Variabel Penalitian. Bandung: Alfabeta

Sugiyono. (2006). Statistika Untuk Penelitian. Bandung: CV Alfabeta.

Danim, S. (2010). Media Komunikasi Pendidikan. Jakarta: PT Bumi Aksara.

Sutirman. (2013). Media dan Model-Model Pembelajaran Inovatif. Yogyakarta: Graha Ilmu.

Fajriah, U.N. (2016). Utilizing Instructional Media for Teaching Infrastructure Administration. Journal of Education and Practice (Online), 7(6), pp. 100-111.

Sadiman, A. S. dkk. (2011). Media Pendidikan: Pengertian, Pengembangan dan Pemanfaatannya. Jakarta: Raja Grafindo Persada. 